\title{
The tensile root strength of Spartina patens declines with exposure to multiple stressors
}

\author{
Lauris O. Hollis $\cdot$ R. Eugene Turner
}

Received: 15 September 2018/Accepted: 10 December 2020/Published online: 5 January 2021

(C) The Author(s) 2021

\begin{abstract}
Coastal wetlands may be subjected to numerous biotic and abiotic stressors from natural and anthropogenic forces in the landscape. The influx of nutrients, inorganic compounds and xenobiotics are suspected of degrading the belowground biomass of coastal macrophytes. Spartina patens acts as an ecosystem engineer for lower salinity coastal marshes and its biomechanical properties are vital to the stability and resilience of coastal wetlands. S.patens was exposed to one natural (flooding) and two anthropogenic stressors (atrazine and nutrient addition) in a greenhouse experiment to test the hypothesis that these three stressors reduce the tensile root strength of S. patens. A one-way Welch's analysis of variance revealed that the tensile root strength $S$. patens significantly declined after exposure to two
\end{abstract}

Supplementary Information The online version contains supplementary material available at https://doi.org/10.1007/ s11273-020-09774-5.

L. O. Hollis $(\bowtie)$

National Academies Of Sciences Engineering And

Medicine, Washington D.C., NW, USA

e-mail: lauris.hollis@gmail.com

L. O. Hollis

P.O. Box 605, Alvin, TX 77512, USA

R. E. Turner

Department of Oceanography and Coastal Sciences, Louisiana State University, 1193 Energy Coast and Environment Building, Baton Rouge, LA 70803, USA flood duration regimes, three levels of atrazine exposure, and two levels of nutrient addition that consisted of nitrogen-phosphorus combinations. A one-way ANOVA of tensile root strength with an atrazineflood duration-nutrient addition combination treatment as the main effect resulted in a 52 to $63 \%$ loss in tensile strength, while the individual atrazine, flooding, and nutrient treatments produced 40,39 , and $37 \%$ losses in tensile root strength, respectively. These results indicate that the effects of multiple natural and/ or anthropogenic stressors may degrade the tensile root strength of $S$. patens, which could facilitate coastal erosion and subsequent collapse of the wetland ecosystem.

Keywords Tensile strength · Roots - Wetlands · Atrazine $\cdot$ Nutrients

\section{Introduction}

Coastal wetland ecosystems are uniquely threatened because of dense human populations in their midst. Crowell et al. (2010) reported that $39 \%$ of the population of the United States lived in counties directly adjacent to the coast. The human population can introduce a plethora of anthropogenic xenobiotics into coastal environments such as petroleum byproducts, human personal care products, pesticides, and excessive sediment and nutrient loads. As a result, 
wetland ecosystems may be subjected to multiple stressors that disrupt or compromise vital ecosystem functions and services. For example, extensive anthropogenic habitat destruction and landscape alteration have modified natural hydrologic regimes (Mitsch and Gosselink 2000; Keddy 2010).

Flood control efforts such as stream channelization, dams, levees, and river diversions have disrupted the natural hydropattern of wetlands and led to excessive inundation and extended floodwater residence time in wetlands (Mitsch and Gosselink 2000; Jackson 2006; Keddy 2010; Willey 2016). Flooding induces oxygen stress on wetland plants because inundated soils severely curtail gas transport and exchange between plants and the atmosphere. In addition, saturated soils produce lower reduction-oxidation potentials (hereafter, redox potential), which can facilitate the accumulation of compounds that are toxic to plants such as soluble $\mathrm{Fe}^{2+}$ and $\mathrm{Mn}^{2+}$, sulfides, ethanol, acetaldehyde, acetic acid, lactic acid and formic acid (Kozlowski 1984; Armstrong et al. 1994; Cronk and Fennessy 2001; Evans 2003; Fieldler et al. 2007; Reddy and Delaune 2008; Striker 2012). Floodinduced stress can also inhibit photosynthesis and reduce carbon fixation within the plant (Justin and Armstrong 1987; Colmer and Voesenek 2009,)

Photosynthesis may also be inhibited by the action of herbicides such as atrazine (6-chloro-N-ethyl-N-(1methylethyl)-1,3,5-triazine-2,4-diamine), which target the transfer of electrons to Photosystem II (Solomon et al. 1996; Krieger-Liszkay and Rutherford 1998; Fufezan et al. 2002; Ghosh and Philip 2006; USEPA 2016). The interruption of electron transfer during this phase of photosynthesis prevents the synthesis of adenosine triphosphate (ATP) for energy replenishment. However, the lethal mode of action of atrazine is the result of oxidative stress, rather than starvation (Zhu et al. 2009). The blockage of electron transfer during photosynthesis induces a rapid and prolonged accumulation of reactive oxygen species (ROS), such as superoxide, peroxide, and a hydroxyl radical, which can oxidize plant tissue (Dat et al. 2000; Sharma et al. 2012; Weerakoon et al. 2018).

Nonpoint pollution from excessive nutrient loading has also been implicated in coastal wetland loss. Many researchers have demonstrated that excess nutrient influxes to coastal wetlands have led to higher rates of soil respiration (Morris and Bradley 1999; Wigand et al. 2009), a reduction in belowground biomass
(Valiela et al. 1976; Morris and Bradley 1999; Darby and Turner 2008a; Deegan et al. 2012; Graham and Mendelssohn 2014, 2016) and lower soil strength (Darby and Turner 2008b; Swarzenski et al. 2008; Turner et al. 2009; Turner 2011). As a result, eutrophic conditions and flood adaptations may reduce root biomass and compromise tensile root strength.

Multiple stressors that weaken the belowground biomass of wetland plants may reduce the resistance of the vegetation community to biomechanical forces that can erode the resilience of the ecosystem. For example, Naidoo et al. (1992) found increased alcohol dehydrogenase activity in Spartina patens in salinity treatments under hypoxic conditions, which was an indication of inadequate aerenchyma development to support aerobic root respiration. The decrease in gas exchange could induce a shift to anaerobic respiration, which would increase the carbon demand and weaken the structural integrity of the roots, and thereby increase the probability of plant loss to erosion. The uprooting and loss of coastal wetland plants can accelerate the erosion of coastal wetlands and force a regime shift into an open water estuarine habitat that will result in the collapse of the wetland ecosystem. Consequently, coastal wetlands that are subjected to multiple stressors may undergo changes in plant communities, increased erosion, altered biogeochemical cycles, and diminished the ecosystem services and functions that help sustain human communities. The biomass of roots and rhizomes may be reduced by the formation of aerenchyma under flooded conditions because lacunae occupy a greater percentage of crosssectional area of the cortex and this may affect the structural integrity of the root (Justin and Armstrong 1987; Seago et al. 2005). Tensile root strength, which is the resistance of a material to a tensional load, is an important component of a plant's structural integrity. Therefore, the determination of the tensile root strength of a dominant coastal macrophyte such as Spartina patens may be used to measure the resistance of the coastal plant community to erosive forces and to ascertain the resilience of coastal wetland ecosystems.

The objective of this study was to investigate the effects of flood duration and different combinations of nutrient addition and atrazine exposure on the tensile root strength of the wetland macrophyte $S$. patens. This study tested the hypotheses that simultaneous exposure to extended flood duration, atrazine, and nutrient addition will cause a reduction in the tensile 
root strength of $S$. patens that is greater than the effects of either individual stressor acting alone.

\section{Materials and methods}

Experimental design and setup

The experiment was conducted under natural light conditions in the greenhouses of Louisiana State University at Baton Rouge, LA. Spartina patens plugs were obtained from the Green Seasons Nursery in Tampa, FL. The samples were transplanted to $9.45 \mathrm{~L}$ plastic pots filled with $5.5 \mathrm{~L}$ of a mixture of $65 \%$ sphagnum peat (Premier Sphagnum Peat Moss; $100 \%$ Canadian peat moss, no added fertilizer or nutrients), $30 \%$ clay/silt mixture, and 5\% sand. The sand, silt, and clay components were obtained from the Sterlington soil series (coarse-silty, mixed thermic Typic Hapludalfs) in the Mississippi River floodplain in West Baton Rouge Parish by LSU greenhouse staff. The soil texture of clay/silt components was estimated by texture-by-feel field technique and determined to be sandy clay loam. The treatments were rotated monthly on a reverse-orientation basis (e.g. from south to north, and west to east) during the experiment to reduce the variation in environmental conditions.

The experiment treatments consisted of three main effects: Atrazine exposure, flood duration, and nutrient addition; and combination treatments in which experimental units were simultaneously subjected to atrazine, flooding, and nutrient addition. We did not use a factorial design. Instead, the combination treatments were made by combining the three levels of atrazine with the two levels of the flood duration treatment and the two levels of the nutrient addition treatment, which resulted in 12 different combination treatments (Appendix A). All treatments had four replicates, including the Control. The monthly atrazine treatments were: High $\left(5.0 \mu \mathrm{g}\right.$ per liter $\left.\left[\mu \mathrm{g} \mathrm{L}^{-1}\right]\right)$, Medium $\left(3.0 \mu \mathrm{g} \mathrm{L}^{-1}\right)$, and Low $\left(1.0 \mu \mathrm{g} \mathrm{L}^{-1}\right)$. In addition, there were four deionized water disturbed controls with no plants in clear, $3.78 \mathrm{~L}$ glass jars that were treated with a $3.0 \mu \mathrm{g} \mathrm{L}^{-1}$ atrazine solution on a monthly basis. The nitrogen and phosphorus nutrient treatments consisted of granular reagent grade calcium nitrate tetrahydrate $\left[\mathrm{Ca}\left(\mathrm{NO}_{3}\right)_{2} \cdot 4 \mathrm{H}_{2} \mathrm{O}\right]$ and granular laboratory grade potassium phosphate $\left[\mathrm{K}_{3} \mathrm{PO}_{4}\right]$ (Fisher Scientific; Nazareth, PA). Nutrient treatments were also added monthly as High Nitrogen-High Phosphorus (NP), and Low Nitrogen- Low Phosphorus (np) combinations at the following levels: High Nitrogen (HN, $5.0 \mathrm{mg} \mathrm{L}{ }^{-1}$ ), Low Nitrogen (LN, $1.75 \mathrm{mg} \mathrm{L}^{-1}$ ), High Phosphorus (HP, $0.30 \mathrm{mg} \mathrm{L}^{-1}$ ), Low Phosphorus (LP, $0.10 \mathrm{mg} \mathrm{L}^{-1}$ ). The nutrient and atrazine treatments were based on ambient levels in the Lower Mississippi River and data compiled by the United States Geological Survey during the 2011 Mississippi River flood (Welch et al. 2014).

The flood duration treatment consisted of placing each 9.45 L plastic pot inside an 18.9 L high-density plastic bucket and filling the bucket with deionized water to $15 \mathrm{~cm}$ above the soil surface. The flood duration treatments were $50 \%$ of the designated time frames after Visser and Sandy (2009): Bi-Weekly (14 days: 7 days flooded, 7 days saturated) and Monthly (30 days: 15 days flooded, 15 days saturated). The flood/drained cycle was repeated throughout the duration of the experiment. Water levels were manipulated by placing bricks underneath the plastic pots during the drained period and removing the bricks during the flood period. During the drained phase, water levels were maintained $\sim 1.75 \mathrm{~cm}$ above the soil surface to ensure saturated soil conditions. The controls were pots with continuously saturated soil with no atrazine or nutrient treatments.

Soil temperature, $\mathrm{pH}$, and redox potential were measured monthly in the combination treatment units only, before the addition of nutrients and atrazine. Soil temperature was measured by a soil probe thermometer to the nearest $0.1{ }^{\circ} \mathrm{C}$. The $\mathrm{pH}$ of the soil was measured in pore water collected using a Lisle vacuum pump (Lisle Corporation, Clarinda, Iowa) and measured by a Hach HQ 40d multi-parameter meter (Hach Industries Loveland, CO). Redox potential was measured with $45 \mathrm{~cm}$-long standard platinum probes according to Reddy and Delaune (2008) and a Corning calomel reference probe (Corning, Inc. Corning, NY) that were connected to a Fluke 73 Multimeter (John Fluke Manufacturing, Everett WA). A correction of $+244 \mathrm{mV}$ was added to redox measurements after Reddy and Delaune (2008). The experiment was 
conducted for a total of 123 days from 1 May 2016 to 31 August 2016.

Tensile strength testing

Tensile strength testing was conducted only on live roots. A small size class $(0.5-1.0 \mathrm{~mm})$ was selected for testing because of the high numbers of roots within this diameter range and the increased probability of conducting successful tensile strength tests. A mean of six tests were conducted for every successful tensile strength test. A successful test consisted of root samples that failed between the supports of the test stand, whereas roots that failed at the supports were considered unsuccessful tests. Live roots and rhizomes were differentiated from dead roots by their white, turgid, and translucent appearance while dead roots were dark and flaccid (Darby and Turner 2008a, b). However, many live roots were stained by soil deposits and they were separated from dead roots by the presence of turgor, bifurcations of fine roots, and their ability to float. Three individual root metrics were measured: mass, length, and diameter. Crosssectional area $\left(\mathrm{mm}^{2}\right)$ and volume $\left(\mathrm{mm}^{3}\right)$ were calculated from length and diameter measurements after measuring tensile strength. Root length was measured to the nearest $0.1 \mathrm{~mm}$ with a Scale Master@ Classic digital plan measuring tool (Calculated Industries, Carson, NV USA). The mean root diameter was measured to the nearest $0.1 \mathrm{~mm}$ with a Starrett digital IP67 micrometer. The measurements were taken at both ends and at the middle of each root and averaged. Root samples were weighed to the nearest $0.1 \mathrm{mg}$ (mg) to estimate individual mass. A Mecmesin MultiTest 1-d motorized stand (Mecmesin Limited; Sinfold, West Sussex, UK) was used to test tensile root strength in Newtons $(\mathrm{N})$. Individual roots were secured to two support clamps that were perpendicular to the base of the test stand. The contact surfaces of the clamps provided $1.25 \times 2.50 \mathrm{~cm}$ of area and were lined with fine sandpaper to reduce or eliminate slippage. The test stand was activated and the top support was pulled upward by a vertical hydraulic piston until the root exhibited structural failure. The load that induced failure at that point, or breaking force, was recorded as tensile root strength.
Tissue sample testing

Samples of live leaf and root tissue of each experimental unit and the control were collected at the end of the experiment and after tensile strength testing and then sent to the LSU Soil Testing and Plant Analysis Laboratory for carbon, nitrogen, and phosphorus tissue content testing. The laboratory analyzed plant samples for carbon and nitrogen with a LECO CN 2000 Analyzer using the Dumas dry combustion method (Wright and Bailey 2001). The LSU Department of Agricultural Chemistry analyzed water, soil, and root samples for atrazine, deethylatrazine, and deisopropylatrazine concentration with gas chromatography-mass spectrometry (GC-MS) analysis using standard operating procedures that were modified from United States Environmental Protection Agency (USEPA) Methods 525,507-1, and 507-2.

\section{Statistical analyses}

We conducted an analysis of variance (ANOVA) using JMP v. 13 software (SAS Cary, NC) to test for differences in the mean tensile root strength in the experimental units subjected to atrazine, nutrient, flood duration, and combination treatments. Significant differences between the tensile root strength means were determined using a Tukey-Kramer Honest Significant Difference (HSD) test. The data are reported as the mean \pm 1 standard error of the mean unless otherwise noted. Homoscedasticity and normality of residuals were determined with Brown-Forsythe and Shapiro-Wilks tests, respectively. Data that did not meet the assumptions of ANOVA were tested with a Welch's ANOVA, and differences between the tensile strength means were determined using a Steel-Dwass nonparametric multiple comparison test. Statistical significance of the soil temperature, redox potential, and $\mathrm{pH}$ parameter data were tested using a one-way ANOVA. The differences in the carbon, nitrogen, and phosphorus content among the nutrient treatments in both the roots and shoots were also tested with a oneway ANOVA and differences between the means were determined using a Tukey-Kramer HSD post-hoc test. All statistical tests were performed at a significance level of $p<0.05$. 


\section{Results}

Tensile root strength

A one-way Welch's ANOVA with atrazine as the main effect revealed significant differences in tensile root strength between the three levels of atrazine and Control (Fig. 1, $F=39.0, p<0.0001$ ). The Control tensile root strength was two times stronger than that of plants exposed to atrazine (Fig. 1). There were no significant differences in tensile root strength between the High, Medium, and Low treatments.

A one-way Welch's ANOVA with flood duration as the main effect revealed significant differences in tensile root strength between the two levels of flood duration and Control (Fig. 2, $F=56.3, p<0.0001$ ). There was no significant difference in tensile root strength between the Bi-Weekly and the Monthly treatments.

A one-way Welch's ANOVA with nutrient addition as the main effect revealed significant difference in tensile root strength between the two levels of nutrient addition and Control (Fig. 3, $F=56.2, p<0.0001$ ). There was no significant difference in tensile root strength between the High Nitrogen-High Phosphorus (NP) and the Low Nitrogen-Low Phosphorus (np) treatments.

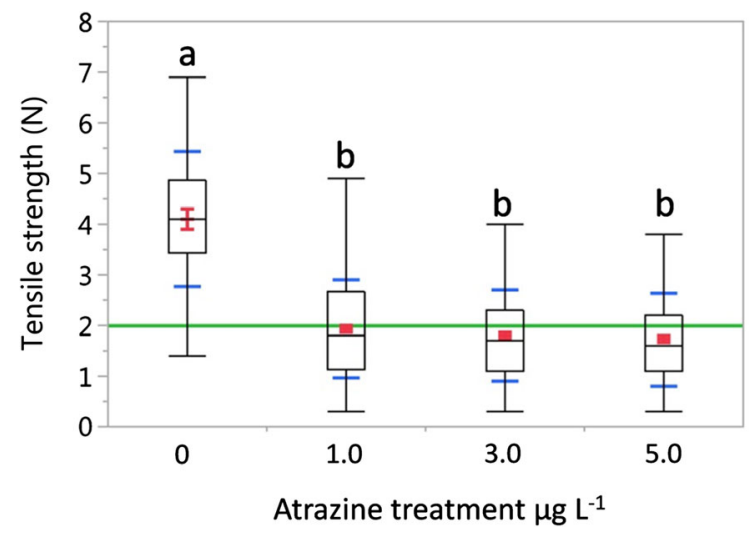

Fig. 1 Box and whisker plot of one-way Welch's ANOVA of tensile root strength with atrazine as the main effect for the combined atrazine-flood duration-nutrient greenhouse experiment. There were significant differences between control and atrazine treatments $(\mathrm{p}<0.0001)$. The box plot whiskers represent the range; the blue horizontal lines denote \pm 1 standard deviation; the center horizontal red lines represent the group mean \pm 1 standard error; the horizontal green line across the plot is the grand mean. Box plots with different letters denote significant differences between treatments

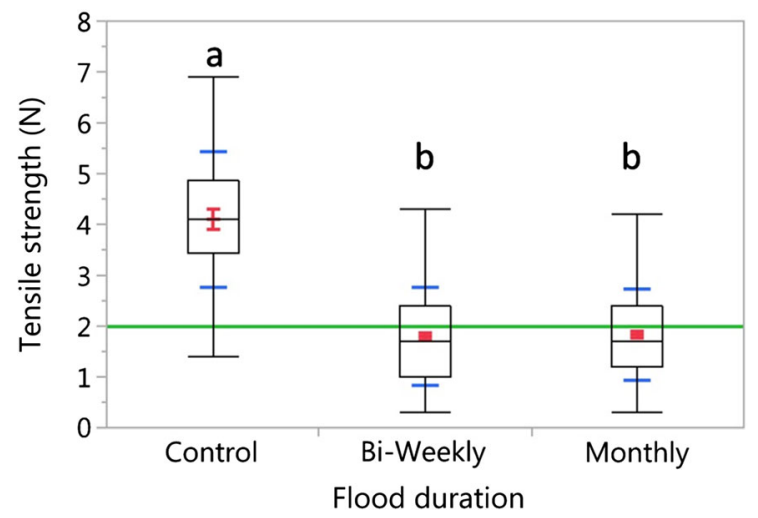

Fig. 2 Box and whisker plots of one-way Welch's ANOVA of tensile root strength with flood duration as the main effect for the combined atrazine-flood duration-nutrient greenhouse experiment. There were significant differences between control and flood duration treatments (Table 6.1, $\mathrm{p}<0.0001$ ). The box plot whiskers represent the range; the blue horizontal lines denote \pm 1 standard deviation; the center horizontal red lines represent the group mean \pm 1 standard error; the horizontal green line across the plot is the grand mean. Box plots with different letters denote significant differences between treatments

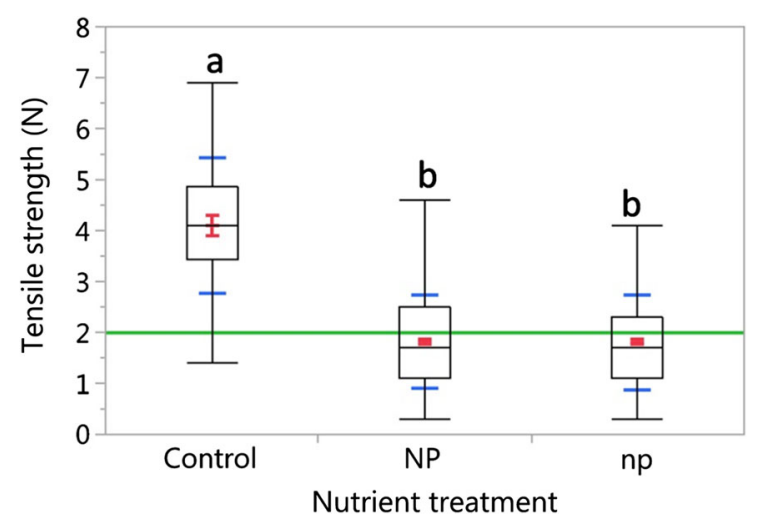

Fig. 3 One-way Welch's ANOVA of tensile root strength with nutrient addition as the main effect for the combined atrazineflood duration-nutrient greenhouse experiment. There were significant differences between control and nutrient treatments $(\mathrm{p}<0.0001)$. The box plot whiskers represent the maximum and minimum values. The blue horizontal lines denote \pm 1 standard deviation. The center horizontal red line represents the group mean and the two red lines above and below represents \pm 1 standard error of the mean. The horizontal green line across the plot is the grand mean

A one-way ANOVA of tensile root strength revealed significant differences between the 12 combination treatments and Control (Fig. 4, $F=18.4$, $p<0.0001)$. There were no significant differences in tensile root strength among the combination 


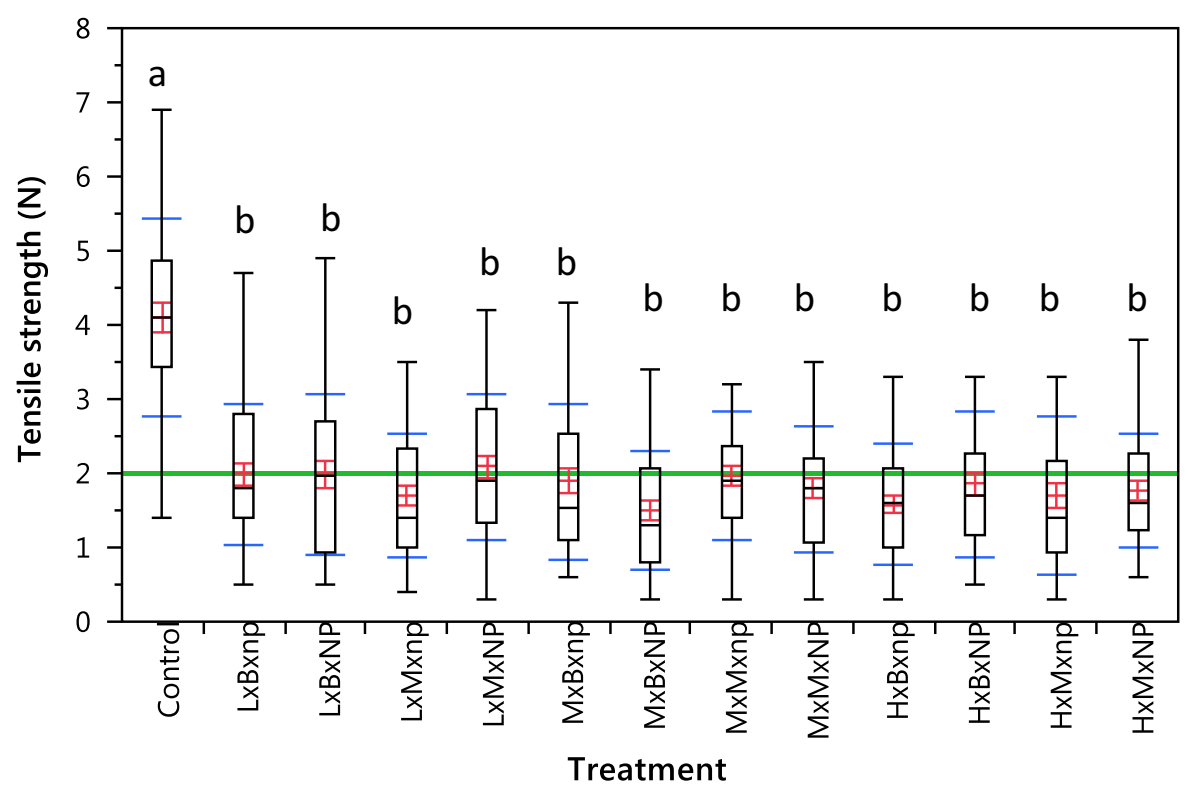

Fig. 4 One-way ANOVA of tensile root strength with atrazineflood duration -nutrient addition combination treatment as the main effect. There were significant differences between control and all combination treatments $(\mathrm{p}<0.0001)$. The box plot whiskers represent the maximum and minimum values. The blue

treatments. The greatest loss in tensile root strength was observed in the Medium Atrazine $\times$ Bi-Weekly Flood Duration $\times$ High Nitrogen-High Phosphorus (MxBxNP; 1.50 N, Fig. 4, Table 1) and High Atrazine $\times$ Bi-Weekly Flood Duration $\times$ Low Nitrogen-Low Phosphorus (HxBxnp; 1.58 N, Fig. 4, Table 1) treatments. The tensile root strength of the MxBxNP and HxBxnp units were $63 \%$ and $61 \%$ less, respectively, than the Control.

\section{Soil parameters}

The soil properties from the combination treatment units were analyzed by using the flood duration treatment levels because flooding directly affects soil temperature, $\mathrm{pH}$, and redox potential. A one-way ANOVA revealed no significant difference in soil temperature between the two flood duration treatment levels or Control (Table 2; Appendix B, Fig. B1; $F=0.137, p=0.873)$. However, there were significant differences in soil $\mathrm{pH}$ between the two flood duration treatment levels and the Control (Table 2; Appendix B, Fig. B2; $F=12.3, p=0.002$ ), but there was no significant difference in soil $\mathrm{pH}$ between the two flood duration treatments. Also, there were no horizontal lines denote \pm 1 standard deviation. The center horizontal red line represents the group mean and the two red lines above and below represents \pm 1 standard error of the mean. The horizontal green line across the plot is the grand mean

significant differences in redox potential between the two flood duration treatment levels or the Control (Table 2; Appendix B, Fig. B3; $F=0.004, p=0.995$ ).

Plant tissue nutrient content

A one-way ANOVA revealed that the carbon content (mmol $\mathrm{g}^{-1}$ dry weight) in the aboveground (stem) and belowground tissue (roots) of $S$. patens nutrient treatments was significantly different from the Control (Table 3, $F=14.5, p<0.0001$ ). The carbon content for the NP and np nutrient treatments in both the roots and stem was higher than Control. Also, more carbon was detected in the roots than in the aboveground tissue. The plants of the NP treatment contained greater concentrations of nitrogen and phosphorus in the roots than in the stem. The nitrogen content of both nutrient treatments was higher than the Control; however, there were significant differences in nitrogen content between the aboveground (Table 3, $F=72.1$, $p<0.0001$ ) and belowground tissue (Table 3, $F=5.28, p=0.0097)$ and Control. The phosphorus content of the nutrient treatments in both the roots and stem was also higher than the Control. One-way ANOVAs found significant difference in the 
Table 1 Summary statistics of the tensile root strength $(\mathrm{N})$ response variable for the nutrient, atrazine, and flood duration main effects and combination treatments

\begin{tabular}{|c|c|c|c|c|c|c|c|c|c|}
\hline Source & $\mathrm{n}$ & Max & Min & Mean & Group mean & Grand mean & SE & SD & $p$-value \\
\hline Atrazine & 160 & $\mathrm{n} / \mathrm{a}$ & $\mathrm{n} / \mathrm{a}$ & $\mathrm{n} / \mathrm{a}$ & 1.83 & 2.46 & $\mathrm{n} / \mathrm{a}$ & $\mathrm{n} / \mathrm{a}$ & $<0.0001$ \\
\hline Control & 40 & 7.1 & 1.4 & 4.10 & $\mathrm{n} / \mathrm{a}$ & $\mathrm{n} / \mathrm{a}$ & 0.15 & 1.33 & $\mathrm{n} / \mathrm{a}$ \\
\hline Low & 40 & 4.9 & 0.3 & 1.94 & $\mathrm{n} / \mathrm{a}$ & $\mathrm{n} / \mathrm{a}$ & 0.09 & 0.97 & $<0.0001$ \\
\hline Medium & 40 & 4.7 & 0.3 & 1.79 & $\mathrm{n} / \mathrm{a}$ & $\mathrm{n} / \mathrm{a}$ & 0.08 & 0.90 & $<0.0001$ \\
\hline High & 40 & 5.8 & 0.3 & 1.72 & $\mathrm{n} / \mathrm{a}$ & $\mathrm{n} / \mathrm{a}$ & 0.08 & 0.91 & $<0.0001$ \\
\hline Flood duration & 120 & $\mathrm{n} / \mathrm{a}$ & $\mathrm{n} / \mathrm{a}$ & $\mathrm{n} / \mathrm{a}$ & 1.82 & 2.51 & $\mathrm{n} / \mathrm{a}$ & $\mathrm{n} / \mathrm{a}$ & $<0.0001$ \\
\hline Control & 40 & 7.1 & 1.4 & 4.10 & $\mathrm{n} / \mathrm{a}$ & $\mathrm{n} / \mathrm{a}$ & 0.15 & 1.33 & $\mathrm{n} / \mathrm{a}$ \\
\hline Bi-Weekly & 40 & 4.9 & 0.3 & 1.80 & $\mathrm{n} / \mathrm{a}$ & $\mathrm{n} / \mathrm{a}$ & 0.07 & 0.96 & $<0.0001$ \\
\hline Monthly & 40 & 5.8 & 0.3 & 1.84 & $\mathrm{n} / \mathrm{a}$ & $\mathrm{n} / \mathrm{a}$ & 0.06 & 0.90 & $<0.0001$ \\
\hline Nutrient & 120 & $\mathrm{n} / \mathrm{a}$ & $\mathrm{n} / \mathrm{a}$ & $\mathrm{n} / \mathrm{a}$ & 1.81 & 2.66 & $\mathrm{n} / \mathrm{a}$ & $\mathrm{n} / \mathrm{a}$ & $<0.0001$ \\
\hline Control & 40 & 7.1 & 1.4 & 4.10 & $\mathrm{n} / \mathrm{a}$ & $\mathrm{n} / \mathrm{a}$ & 0.15 & 1.33 & $\mathrm{n} / \mathrm{a}$ \\
\hline High Nitrogen-Phosphorus (NP) & 40 & 4.9 & 0.3 & 1.82 & $\mathrm{n} / \mathrm{a}$ & $\mathrm{n} / \mathrm{a}$ & 0.06 & 0.93 & $<0.0001$ \\
\hline Low Nitrogen-Phosphorus (np) & 40 & 5.8 & 0.3 & 1.81 & $\mathrm{n} / \mathrm{a}$ & $\mathrm{n} / \mathrm{a}$ & 0.06 & 0.94 & $<0.0001$ \\
\hline Low & 200 & $\mathrm{n} / \mathrm{a}$ & $\mathrm{n} / \mathrm{a}$ & $\mathrm{n} / \mathrm{a}$ & 1.94 & 2.37 & $\mathrm{n} / \mathrm{a}$ & $\mathrm{n} / \mathrm{a}$ & $<0.0001$ \\
\hline Control & 40 & 7.1 & 1.4 & 4.10 & $\mathrm{n} / \mathrm{a}$ & $\mathrm{n} / \mathrm{a}$ & 0.17 & 1.33 & $\mathrm{n} / \mathrm{a}$ \\
\hline LxBxnp & 40 & 4.7 & 0.5 & 1.98 & $\mathrm{n} / \mathrm{a}$ & $\mathrm{n} / \mathrm{a}$ & 0.18 & 0.96 & $<0.0001$ \\
\hline LxBxNP & 40 & 4.9 & 0.5 & 1.99 & $\mathrm{n} / \mathrm{a}$ & $\mathrm{n} / \mathrm{a}$ & 0.15 & 1.08 & $<0.0001$ \\
\hline LxMxnp & 40 & 3.5 & 0.3 & 1.70 & $\mathrm{n} / \mathrm{a}$ & $\mathrm{n} / \mathrm{a}$ & 0.14 & 0.83 & $<0.0001$ \\
\hline LxMxNP & 40 & 4.2 & 0.2 & 2.08 & $\mathrm{n} / \mathrm{a}$ & $\mathrm{n} / \mathrm{a}$ & 0.16 & 0.98 & $<0.0001$ \\
\hline Medium & 200 & $\mathrm{n} / \mathrm{a}$ & $\mathrm{n} / \mathrm{a}$ & $\mathrm{n} / \mathrm{a}$ & 1.79 & 2.25 & $\mathrm{n} / \mathrm{a}$ & $\mathrm{n} / \mathrm{a}$ & $<0.0001$ \\
\hline Control & 40 & 7.1 & 1.4 & 4.10 & $\mathrm{n} / \mathrm{a}$ & $\mathrm{n} / \mathrm{a}$ & 0.17 & 1.33 & $\mathrm{n} / \mathrm{a}$ \\
\hline MxBxnp & 40 & 4.3 & 0.6 & 1.89 & $\mathrm{n} / \mathrm{a}$ & $\mathrm{n} / \mathrm{a}$ & 0.15 & 1.04 & $<0.0001$ \\
\hline MxBxNP & 40 & 3.4 & 0.2 & 1.50 & $\mathrm{n} / \mathrm{a}$ & $\mathrm{n} / \mathrm{a}$ & 0.15 & 0.81 & $<0.0001$ \\
\hline MxMxnp & 40 & 4.6 & 0.2 & 1.97 & $\mathrm{n} / \mathrm{a}$ & $\mathrm{n} / \mathrm{a}$ & 0.14 & 0.86 & $<0.0001$ \\
\hline MxMxNP & 40 & 4.3 & 0.3 & 1.80 & $\mathrm{n} / \mathrm{a}$ & $\mathrm{n} / \mathrm{a}$ & 0.14 & 0.85 & $<0.0001$ \\
\hline High & 200 & $\mathrm{n} / \mathrm{a}$ & $\mathrm{n} / \mathrm{a}$ & $\mathrm{n} / \mathrm{a}$ & 1.72 & 2.20 & $\mathrm{n} / \mathrm{a}$ & $\mathrm{n} / \mathrm{a}$ & $<0.0001$ \\
\hline Control & 40 & 7.1 & 1.4 & 4.10 & $\mathrm{n} / \mathrm{a}$ & $\mathrm{n} / \mathrm{a}$ & 0.17 & 1.33 & $\mathrm{n} / \mathrm{a}$ \\
\hline HxBxnp & 40 & 3.3 & 0.2 & 1.58 & $\mathrm{n} / \mathrm{a}$ & $\mathrm{n} / \mathrm{a}$ & 0.13 & 0.81 & $<0.0001$ \\
\hline $\mathrm{HxBxNP}$ & 40 & 4.5 & 0.5 & 1.86 & $\mathrm{n} / \mathrm{a}$ & $\mathrm{n} / \mathrm{a}$ & 0.18 & 0.98 & $<0.0001$ \\
\hline HxMxnp & 40 & 6.0 & 0.2 & 1.69 & $\mathrm{n} / \mathrm{a}$ & $\mathrm{n} / \mathrm{a}$ & 0.15 & 1.06 & $<0.0001$ \\
\hline HxMxNP & 40 & 3.7 & 0.6 & 1.77 & $\mathrm{n} / \mathrm{a}$ & $\mathrm{n} / \mathrm{a}$ & 0.15 & 0.77 & $<0.0001$ \\
\hline
\end{tabular}

Statistical significance of the grand means (in bold, Source column) and treatment levels is indicated by $p$-values $<0.05$

phosphorus content in the roots (Table $3, F=8.67$, $p=0.0008$ ) and in the stem (Table 3, $F=42.7$, $p<0.0001)$ than in the Control.

The C:N ratio of the aboveground nutrient treatments was higher than those of belowground nutrient treatments. However, for the $\mathrm{N}: \mathrm{P}$ ratios, the stem ratios in the nutrient treatments were higher than the root ratios. In the roots, the $\mathrm{N}: \mathrm{P}$ ratios ranged from 9.8 in the NP treatment to 12.3 in the Control treatments. In the stems, the $\mathrm{N}: \mathrm{P}$ ratios ranged from 17.8 in the $\mathrm{np}$ treatments to 28.1 in the Control.
Atrazine levels

Neither atrazine nor any of its primary metabolites were detected in leaf, root, or solid soil samples from any of the Low, Medium, or High atrazine experimental treatments $\left(25 \mu \mathrm{g} \mathrm{L}{ }^{-1}\right.$ detection limit). However, atrazine was detected in the soil porewater of the Low, Medium, and High atrazine treatments at a concentration of $0.0083 \mu \mathrm{g} \mathrm{L}^{-1}, 0.0095 \mu \mathrm{g} \mathrm{L}^{-1}$, and $0.0435 \mu \mathrm{g} \mathrm{L}^{-1}$, respectively. In addition, atrazine and deethylatrazine (DEA) were detected in the deionized 
Table 2 Summary of mean soil parameters of a nutrientatrazine-flood duration interaction experiment delineated by flood duration treatment

\begin{tabular}{lccc}
\hline Parameter & \multicolumn{3}{l}{ Experimental treatments } \\
\cline { 2 - 4 } & Bi-Weekly & Monthly & Control \\
\hline Soil Temperature $\left({ }^{\circ} \mathrm{C}\right)$ & & & \\
Mean & 26.0 & 26.2 & 25.9 \\
Min & 25.1 & 25.2 & 25.2 \\
Max & 27.0 & 27.0 & 27.0 \\
Standard Error & 0.43 & 0.44 & 0.50 \\
pH & & & \\
Mean & $7.4^{\mathrm{a}}$ & $7.4^{\mathrm{a}}$ & $7.0^{\mathrm{b}}$ \\
Min & 7.2 & 7.3 & 6.9 \\
Max & 7.5 & 7.5 & 7.1 \\
Standard Error & 0.06 & 0.06 & 0.05 \\
Redox Potential $(\mathrm{mV})$ & & & \\
Mean & 88.0 & 86.2 & 91.3 \\
Min & 6.2 & 2.7 & 33.1 \\
Max & 166.1 & 164.5 & 159.8 \\
Standard Error & 40.2 & 40.0 & 40.4 \\
\hline
\end{tabular}

Mean values with different letter superscripts are significantly different $(p<0.05)$

water controls at mean concentrations of 6.96 and $1.60 \mu \mathrm{g} \mathrm{L}^{-1}$, respectively.

\section{Discussion}

The results from the one-way ANOVAs of the three main effects indicated that the tensile root strength of $S$. patens was significantly reduced by flood duration, atrazine treatment, and nutrient addition. There were no significant differences in tensile root strength among the three main effects.

The most likely consequence of flood duration is the formation of aerenchyma, which appears to immediately reduce tensile root strength because of the loss of tissue and increased root porosity, despite the recalcitrant nature of aerenchyma tissue. As the internal structure of the root is altered, its ability to withstand external loading also may be altered. Before flood adaptations occur, the structure of the root resembles a semi-solid column with numerous horizontal and vertical internal support structures that may have a greater ability to attenuate external tensional loads (Niklas and Spatz 2012). Niklas (1992) stated that it is important to think of the biomechanical properties of a plant as structures such as beams and columns, rather than tissue because forces are exerted on plant tissue from multiple vectors in three dimensions. However, the lysigenous process of lacunae formation reduces this internal support structure to create large pore spaces for gas exchange. As a result, a smaller amount of tissue assumes the load bearing capacity for the root. Mechanical stress is defined as force per unit area and root volume can increase with increasing porosity; therefore, with less tissue and more volume, the 'beams' and 'columns' in the root cortex may then be subjected to more force, stress, and even shear stress. The spans of the 'beams' and 'columns' increases as less structural material support the increased amount of volume. Striker et al. (2007) examined the trade-off between aerenchyma formation and root mechanical strength in four emergent macrophytes (Paspalidium geminatum, Cyperus eragrostis, Rumex crispus and Plantago lanceolata). They concluded that unless the remaining tissue had been reinforced by sclerenchyma, the tensile root strength decreased considerably with increasing porosity regardless of the species. It is unknown how the formation of aerenchyma affects the alignment of macro- and microfibrils, which are the primary, cellulose-rich support elements within the tissue. The alignment of the macrofibrils can affect tensile root strength and even a change in turgor pressure can influence the alignment of the macrofibrils. Cronk and Fennessy (2001) stated that aerenchyma formation may reduce the internal root tissue (parenchyma) by $60 \%$ or more and that aerenchyma formation may continue as the redox potential decreases, which would further increase root porosity. The redox potential for the flood duration treatments dropped to a minimum of $+6.7 \pm 20.8 \mathrm{mV}$ for the Bi-Weekly treatment and $+2.7 \pm 19.9 \mathrm{mV}$ for the Monthly treatment. Consequently, as the soil oxygen levels dropped below the aerobic-anaerobic threshold of + $300 \mathrm{mV}$, aerenchyma tissue formation and root porosity could have increased and facilitated a corresponding reduction in tensile root strength.

The increase in root porosity as an adaptation to flooding may have been exacerbated by the effects of nutrient addition. The addition of calcium nitrate tetrahydrate $\left[\mathrm{Ca}\left(\mathrm{NO}_{3}\right)_{2} \cdot 4 \mathrm{H}_{2} \mathrm{O}\right]$ provided nitrate as an electron acceptor to facilitate metabolic functions and drive nutrient cycling processes such as denitrification 


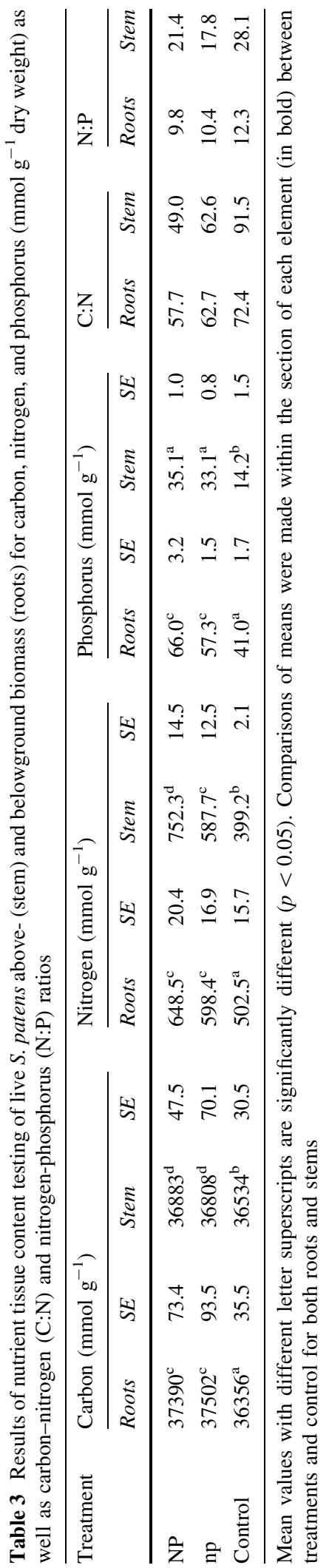

with organic carbon as the electron donor, which may have reduced root biomass. Radial oxygen loss from the roots may not occur along the entire surface area of the root; consequently, nitrate may be used as an alternate electron acceptor during respiration. In addition, the diffusion of oxygen from root to shoot encounters respirative tissue from the root tip to the atmosphere, which could have resulted in additional biomass loss due to aerobic respiration inside the root. The soil temperature increased by $2{ }^{\circ} \mathrm{C}$ from June to July, which may also have increased metabolic reaction rates. The $\mathrm{N}: \mathrm{P}$ ratio for both nutrient treatments were below 15, which is an indication of possible nitrogen growth limitation in wetland plants (Güsewell 2004, Fig. 5).

Root foraging may be curtailed when nutrient levels are in excess of the plant's need (McNickle and Cahill 2009). Darby and Turner (2008b) reported that the belowground biomass of Spartina alterniflora live roots was reduced in 12 out 13 fertilized sites in Massachusetts, Virginia, and Louisiana. They found that sites with the highest belowground biomass in control plots declined by 59\% when fertilized. Turner (2011) found a decrease in soil shear strength below $50 \mathrm{~cm}$ depth in salt marsh plots amended with a $\mathrm{N}+\mathrm{P}$ nutrient addition.

We recognize that the degradation of the belowground biomass may not always manifest as a reduction in mass. This greenhouse study demonstrated that the belowground biomass may remain essentially intact when exposed to nutrient addition but be catastrophically weak when it is evaluated within the context of biomechanical forces. The research described herein expands on the results of Hollis and Turner (2019) who reported results from a factorial experiment with six levels of nutrient treatments and three levels of atrazine doses to test the hypothesis that exposure to nutrients and atrazine reduces the tensile root strength of $S$. patens. Hollis and Turner (2019) clearly showed that nutrient and atrazine treatments $(21 \mu \mathrm{g} \mathrm{L-1}$ of atrazine over 7-weeks) resulted in a significant decrease in the tensile root strength of $S$. patens and the combined nutrient and atrazine treatments also produced a reduction in the belowground biomass. However, this earlier and longer experiment revealed no interactive effects of the nutrient and atrazine treatments.

The multiple stressor experiment described herein included flooding and also produced a reduction in 
tensile root strength by the individual stressors, but the combination treatment caused a greater reduction in tensile root strength without a reduction in the belowground biomass. This experiment did not utilize a factorial design, therefore it is unknown if there were interactive effects between nutrient, atrazine, flood duration treatments. It is well known that atrazine inhibits photosynthesis of aquatic macrophytes (Graymore et al. 2001). Thus, the effects of atrazine on tensile root strength may increase over time and further impair the plant's ability to fix carbon via photosynthesis, and reduce the plant's ability to maintain biomass. The adaptation to facilitate gas exchange may come at the expense of the plant's structural integrity and its relationship to tensile root strength is a recommended focus of future research.

\section{Conclusions}

The tensile root strength of $S$. patens was reduced between 37 and $40 \%$ by individual treatments of flooding, atrazine, and nutrients, and 52-63\% in all of the various treatment combinations. Flooding presumably compromises the physical structure through aerenchyma formation, whereas atrazine exposure is likely to have curtailed the plants' ability to fix carbon for maintenance. As a result, tensile root strength may have declined as the amount of root biomass was reduced. Other outcomes are possible as result of changes in soil temperature, $\mathrm{pH}$, and redox potential. Higher temperatures, for example, increase the rate of metabolic reactions and alkaline conditions can release phosphorus leading to an increase in atrazine availability. Also, root porosity may increase as the plant responds to a lower redox potential by generating more aerenchyma for gas exchange. The effects of these stressors, especially in concert with each other, may increase the wetland's vulnerably to disturbances such as tropical cyclones. There may be a threshold in which ecosystems will transition to another state of equilibrium in which the wetland-dependent organisms do not survive as the accumulated organic peat is exposed, weakened, collapses, and many ecosystem services and functions are lost. Reducing the impacts from multiple stressors would seem to be a more effective management strategy than restoration in this regard.
Acknowledgements We thank Erick Swenson for logistical support and Charles Milan for laboratory assistance. Funding for this research was provided by the Louisiana Board of Regents Graduate Student Fellowship and Shell Biodiversity in Wetlands Graduate Student Support Fund. We appreciated discussing statistical analyses with Edward Laws.

Open Access This article is licensed under a Creative Commons Attribution 4.0 International License, which permits use, sharing, adaptation, distribution and reproduction in any medium or format, as long as you give appropriate credit to the original author(s) and the source, provide a link to the Creative Commons licence, and indicate if changes were made. The images or other third party material in this article are included in the article's Creative Commons licence, unless indicated otherwise in a credit line to the material. If material is not included in the article's Creative Commons licence and your intended use is not permitted by statutory regulation or exceeds the permitted use, you will need to obtain permission directly from the copyright holder. To view a copy of this licence, visit http://creativecommons.org/licenses/by/4.0/.

Funding Funding for this research was provided by the Louisiana Board of Regents Graduate Student Fellowship and Shell Biodiversity in Wetlands Graduate Student Support Fund.

\section{References}

Armstrong W, Brandle R, Jackson MB (1994) Mechanisms of flood tolerance in plants. Acta Bot Neer 43(4):307-358

Colmer TD, Voesenek LJ (2009) Flooding tolerance: suites of plant traits in variable environments. Funct Plant Biol 36:665-681

Cronk JK, Fennessy MS (2001) Wetland plants: Biology and ecology. CRC Press, New York

Crowell M, Coulton K, Johnson C, Wescott J, Bellomo D, Edelman S, Hirsch E (2010) An estimate of the US population living in 100-year coastal flood hazard areas. J of Coast Res 26(2):201-211

Darby FA, Turner RE (2008a) Below- and aboveground biomass of Spartina alterniflora: Response to nutrient addition in a Louisiana salt marsh. Estuar Coasts 31(2):326-334

Darby FA, Turner RE (2008b) Effects of eutrophication on salt marsh root and rhizome biomass accumulation. Mar Ecol Prog Ser 363:63-70

Dat J, Vandenabeele S, Vranova' E, Van Montagu M, Inze' D, Van Breusegem F, (2000) Dual action of the active oxygen species during plant stress responses. Cell Mol Life Sci 57:779-795

Deegan LA, Johnson DS, Warren RS, Peterson BJ, Fleeger JW, Fagherazzi S, Wollheim WM (2012) Nature 490:388-392

Evans DE (2003) Aerenchyma formation. New Phytol 161:35-49

Fiedler S, Vepraskas MJ, Richardson JL (2007) Soil redox potential: Importance, field measurements, and observations. Adv Agron 94:2-56 
Fufezan C, Rutherford AW, Krieger-Liszkay A (2002) Singlet oxygen production in herbicide-treated Photosystem II. FEBS Lett 532:407-410

Ghosh PK, Philip L (2006) Environmental significance of atrazine in aqueous systems and its removal by biological processes: An overview. Glob NEST J 8(2):159-178

Graham SA, Mendelssohn IA (2014) Multiple levels of nitrogen applied to an oligohaline marsh identify a plant community response sequence to eutrophication. Mar Ecol Prog Ser 417:73-82

Graham SA, Mendelssohn IA (2016) Contrasting effects of nutrient enrichment on below-ground biomass in coastal wetlands. J Ecol 104:249-260

Graymore M, Stagniitti F, Allinson G (2001) Impacts of atrazine in aquatic ecosystems. Environ Int 26:483-495

Güsewell S (2004) N: P ratios in terrestrial plants: variation and functional significance. New Phytol 164:201-411

Hollis LO, Turner RE (2019) The tensile root strength of Spartina patens: Response to atrazine exposure and nutrient addition. Wetlands 39(4):759-775. https://doi.org/10. 1007/s13157-019-01126-1

Jackson CR (2006) Wetland hydrology. In: Batzer DP, Sharitz RR (eds) Ecology of estuarine and freshwater wetlands. University of California Press, Los Angeles, CA, pp 43-81

Justin SHFW, Armstrong W (1987) The anatomical characteristics of roots and plant response to soil flooding. New Phytol 106:465-495

Keddy PA (2010) Wetland ecology: Principles and conservation. Cambridge University Press, New York

Krieger-Liszkay A, Rutherford AW (1998) Influence of herbicide binding on the redox potential of the quinone acceptor in Photosystem II: Relevance to photodamage and phytotoxicity. Biochemistry 37(50):17339-17344

Kozlowski TT (1984) Plant responses to flooding of soil. Bioscience 34(3): 162-167

McNickle GG, Cahill JF Jr (2009) Plant root growth and the marginal value theorem. Proc Natl Acad Sci USA 106(12):4747-4751

Mitsch WJ, Gosselink JG (2000) Wetlands, 3rd edn. John Wiley and Sons, Inc., New York

Morris JT, Bradley PM (1999) Effects of nutrient loading on the carbon balance of coastal wetland sediments. Limnol Oceanogr 44(3):699-702

Naidoo G, McKee KL, Mendelssohn IA (1992) Anatomical and metabolic responses to waterlogging and salinity in Spartina alterniflora and $\mathrm{S}$. patens (Poaceae). Am J Bot 79(7):765-770

Niklas KJ (1992) Plant biomechanics: An engineering approach to plant form and function. University of Chicago Press, Chicago

Niklas KJ, Spatz HC (2012) Plant physics. University of Chicago Press, Chicago

Reddy KR, Delaune RD (2008) Biogeochemistry of wetlands: Science and applications. CRC Press, New York

Seago JL Jr, Marsh LC, Stevens KJ, Soukup A, Votrubová O, Enstone DE (2005) A re-examination of the root cortex in wetland flowering plants with respect to aerenchyma. Ann Bot (Lond) 96:565-579

Sharma P, Jha AB, Dubey RS, Pessarakli M (2012) Reactive oxygen species, oxidative damage, and antioxidative defense mechanism in plants under stressful conditions.
Hindawi Publishing Corporation Journal of Botany 2012:1-26

Solomon KR, Baker DB, Richards RP, Dixon KR, Klaine SJ, La Pointe TW, Kendall RJ, Weisskopf CP, Gidding JM, Giesy JP, Hall LW Jr, Williams WM (1996) Ecological risk assessment of atrazine in North American surface waters. Environ Toxicol and Chem 15(1):31-76

Striker GG, Insausti P, Grimoldi AA, Vega AS (2007) Trade-off between root porosity and mechanical strength in species with different types of aerenchyma. Plant Cell Environ 30:580-589

Striker GG (2012) Flooding stress on plants: Anatomical, morphological and physiological responses. In: Mworia J (ed) Botany. Croatia, InTech Europe Rijeka, pp 1-28

Swarzenski CM, Doyle TW, Fry B, Hargis TG (2008) Biogeochemical response of organic-rich freshwater marshes in the Louisiana delta plain to chronic river water influx. Biogeochemistry 90:49-63

Turner RE, Howes BL, Teal JM, Milan CS, Swenson EM, Goehringer-Toner DD (2009) Salt marshes and eutrophication: An unsustainable outcome. Limnol Oceanogr 54(5):1634-1642

Turner RE (2011) Beneath the salt marsh canopy: Loss of soil strength with increasing nutrient loads. Estuar Coasts 33:1084-1093. https://doi.org/10.1007/s12237-010-9341y

United States Environmental Protection Agency (USEPA) (2016) Refined ecological risk assessment for atrazine. Environmental Protection Agency, Washington D.C, Office of Pesticide Programs, U.S

Valiela I, Teal JM, Persson NY (1976) Production and dynamics of experimentally enriched salt marsh vegetation: Limnol. Oceanogr 21(2):245-252

Visser EJW, Sandy ER (2009) The effects of flooding on four common Louisiana marsh plants. Gulf Mex Sci 1:21-29

Weerakoon HPAT, Atapaththu KSS, Asanthi HB (2018) Toxicity evaluation and environmental risk assessment of 2-methyl-4-chlorophenoxy acetic acid (MCPA) on nontarget aquatic macrophyte Hydrilla verticillata. Environ Sci Poll Res 25:30463-30474

Welch HL, Coupe RH, Aulenbach BT (2014) Concentrations and transport of suspended sediment, nutrients, and pesticides in the Lower Mississippi-Atchafalaya River subbasin during the 2011 Mississippi River flood, April through July. US Geological Survey Scientific Investigations Report 2014-5100. https://doi.org/10.3133/sir20145100

Wigand C, Brennan P, Stolt M, Holt M, Ryba S (2009) Soil respiration rates in coastal marshes subject to increasing watershed nitrogen loads in southern New England, USA. Wetlands 29(3):952-963

Willey N (2016) Environmental plant physiology. Garland Science, Taylor and Francis Group, LLC New York

Zhu J, Patzoldt WL, Radwan O, Tranel PJ, Clough SJ (2009) Effects of Photosystem-II-interfering herbicides atrazine and bentazon on the soybean transcriptome. The Plant Genome 2(2):191-205

Publisher's Note Springer Nature remains neutral with regard to jurisdictional claims in published maps and institutional affiliations. 